QA: N/A

TDR-MGR-TH-000001 REV 00

April 2002

\title{
Design Evolution Study: Thermal Operating Methodology
}

By

T.L. Mitchell

Prepared for:

U.S. Department of Energy

Yucca Mountain Site Characterization Office

P.O. Box 364629

North Las Vegas, Nevada 89036-8629

Prepared by:

Bechtel SAIC Company, LLC

1180 Town Center Drive

Las Vegas, Nevada 89144

Under Contract Number

DE-AC08-01RW12101 


\section{DISCLAIMER}

This report was prepared as an account of work sponsored by an agency of the United States Government. Neither the United States Government nor any agency thereof, nor any of their employees, nor any of their contractors, subcontractors or their employees, makes any warranty, express or implied, or assumes any legal liability or responsibility for the accuracy, completeness, or any third party's use or the results of such use of any information, apparatus, product, or process disclosed, or represents that its use would not infringe privately owned rights. Reference herein to any specific commercial product, process, or service by trade name, trademark, manufacturer, or otherwise, does not necessarily constitute or imply its endorsement, recommendation, or favoring by the United States Government or any agency thereof or its contractors or subcontractors. The views and opinions of authors expressed herein do not necessarily state or reflect those of the United States Government or any agency thereof. 
PREDECISIONAL STUDY

Design Evolution Study: Thermal Operating Methodology TDR-MGR-TH-000001 REV 00

April 2002

Prepared by:

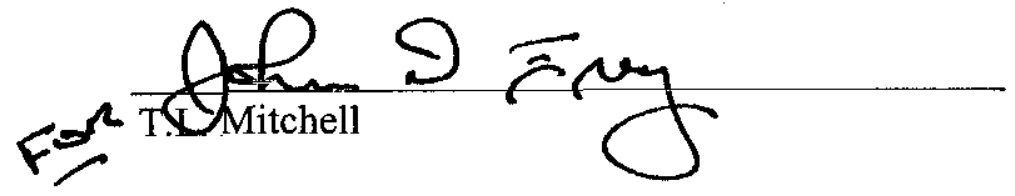

$\frac{4 / 8 / 2002}{\text { Date }}$

Checked by:

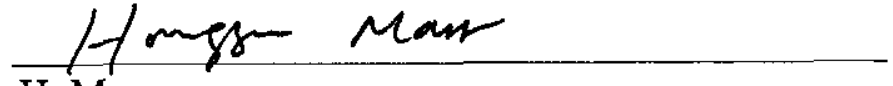

H. War

Reviewed by:

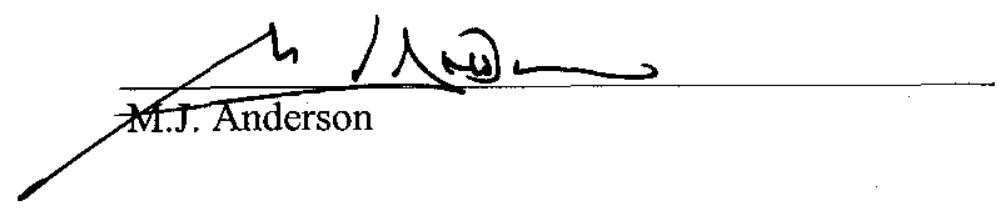

Approved by:

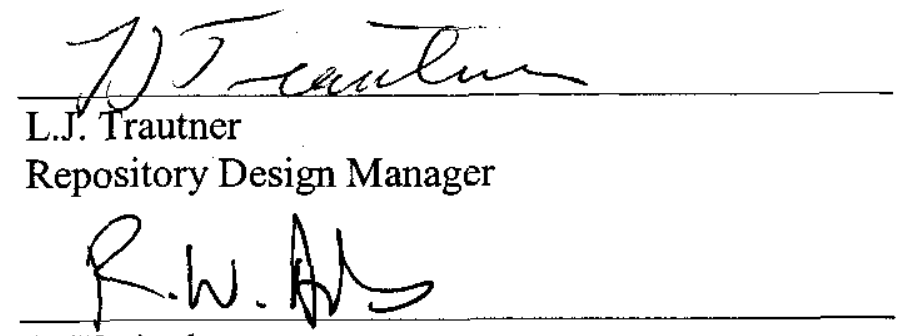

R.W. Andrews

Performance Assume Manager $\frac{4 / 8 / 2002}{\text { Date }}$

$4 / 8 / 02$

Date

$4 / 8 / 02$

Date

$\frac{4 / 8 / 02}{2 a t e}$

TDR-MGR-TH-000001 REV 00

iii

April 2002 
PREDECISIONAL STUDY

\section{INTENTIONALLY LEFT BLANK}




\section{EXECUTIVE SUMMARY}

This study provides results supporting the conclusion that the repository can be operated over a varying range of thermal modes and therefore temperatures. In particular, this work focused on limiting the peak, postclosure waste package surface temperature to less than 85 degrees Celsius, a possible limit due to corrosion considerations. These operating modes were compared by varying the waste package in drift spacing (0.1-2.83 meters), drift pitch (drift spacing centerline to centerline of 40-120 meters), ventilation duration (75-300 years), and ventilation efficiency (50-80\%). The resulting graphical representation shows where the constant temperature of the waste package ( 85 degrees Celsius) lies with respect to drift pitch and waste package spacing.

The waste considered in this study is the strict youngest fuel first 5 years old fuel. Using only strict youngest fuel first 5 years old fuel in the waste stream results in an average heat load per waste package of $12.48 \mathrm{~kW} / \mathrm{Pkg}$. With this high average heat load, it is not possible to achieve a maximum waste package surface temperature of 85 degrees Celsius or less. By aging $63 \%$ of the strict youngest fuel first 5 years old fuel for 27 years, it becomes possible to maintain the waste package surface temperature at 85 degrees Celsius or less. The 27 years of aging comes from the fact that the repository could be closed in as little as 50 years. It takes 23 years to emplace the waste and therefore the last fuel received for emplacement is 27 years prior to closures. The strict youngest fuel first 5 years old fuel waste stream with $63 \%$ aged for 27 years, results in an average power level of $8.4 \mathrm{~kW} / \mathrm{Pkg}$. This lower heat load allows the controlled parameters of drift pitch, waste package spacing, aging, and ventilation duration to be varied to achieve the desired results.

This study compares the hot strict youngest fuel first 5 years old fuel to the previous waste stream, which has an average of 26-year-old fuel. The 26-year-old fuel waste stream has an average power level of $7.2 \mathrm{~kW} / \mathrm{Pkg}$. This comparison illustrated how the parameters important to thermal performance differ for these two assumptions about the waste stream. 
PREDECISIONAL STUDY

\section{INTENTIONALLY LEFT BLANK}


$\underline{\text { PREDECISIONAL STUDY }}$

\section{CHANGE HISTORY}

Revision Interim Effective

$\underline{\text { Number }}$ Change No. Date $\underline{\text { Description of Change }}$

0

0

Initial issue 
PREDECISIONAL STUDY

\section{INTENTIONALLY LEFT BLANK}




\section{CONTENTS}

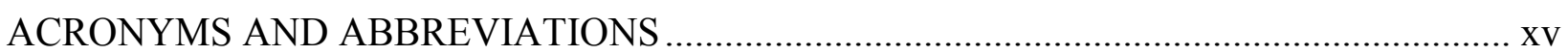

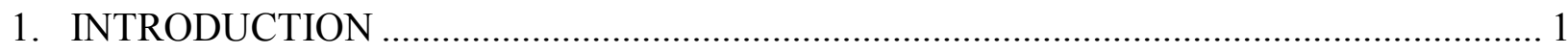

$1.1 \quad$ PURPOSE

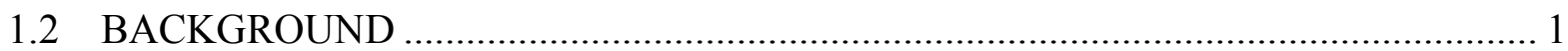

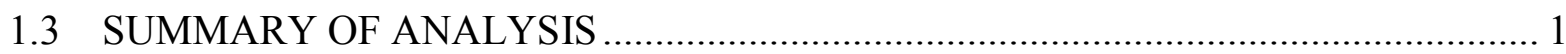

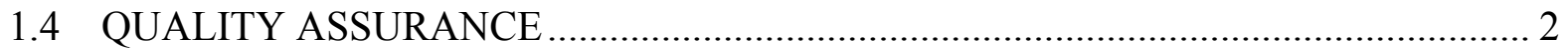

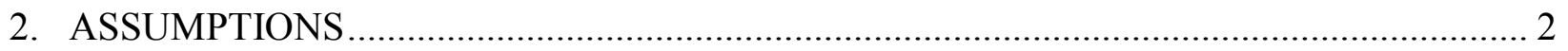

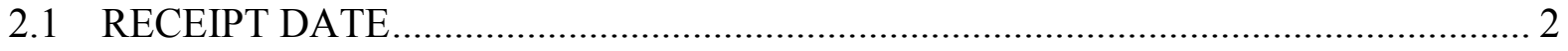

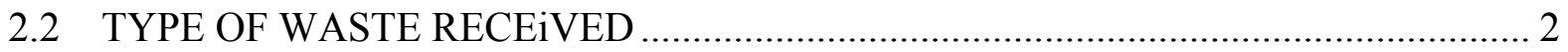

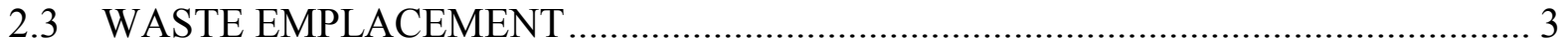

2.4 REPOSITORY DESIGN AND OPERATIONS ASSUMPTION BOUNDS................... 3

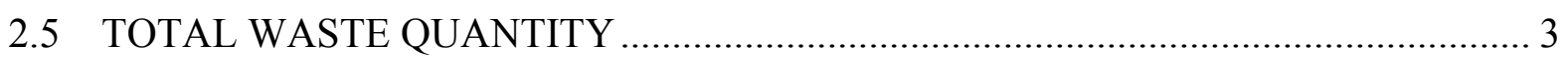

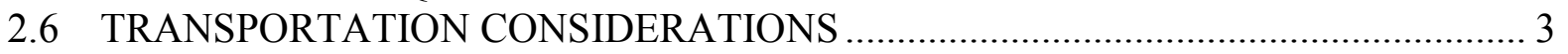

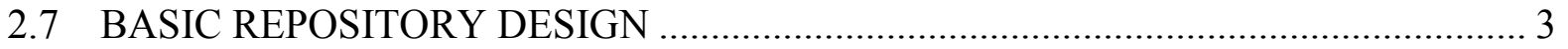

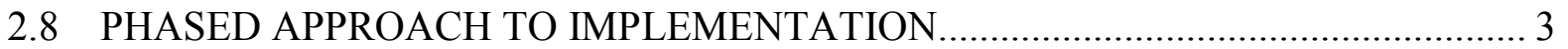

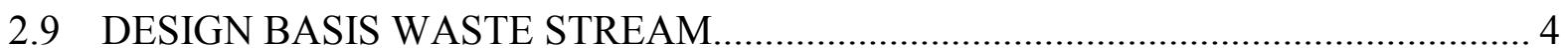

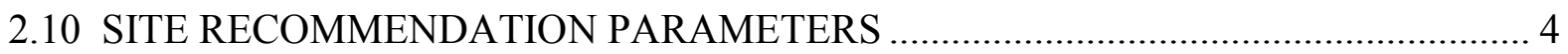

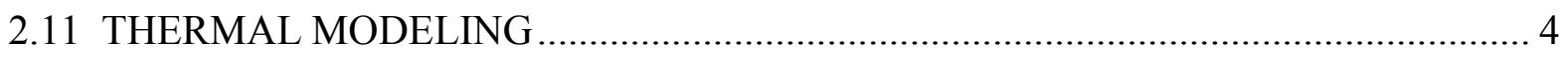

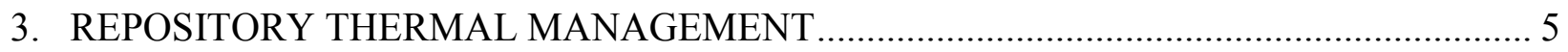

3.1 THE WASTE STREAM THERMAL LOAD …………...................................... 5

3.2 THE CONTROL OF REPOSITORY TEMPERATURE .............................................. 6

3.3 GENERAL METHODS FOR CONTROL OF REPOSITORY TEMPERATURE ......... 7

3.4 FUNCTIONAL ANALYSIS OF THERMAL OPERATIONS ..................................... 8

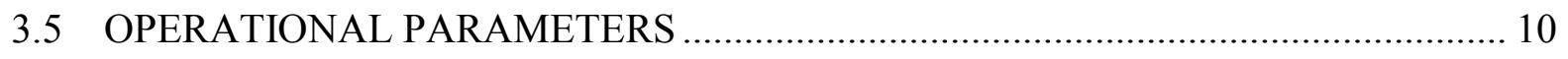

4. THERMAL OPERATIONS METHODOLOGY ALTERNATIVES ….................................. 16

4.1 NULL ALTERNATIVE (Figure 4-1) .................................................................... 17

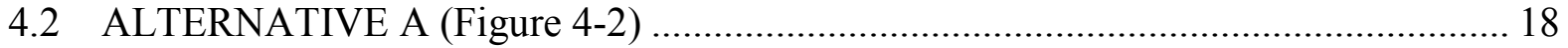

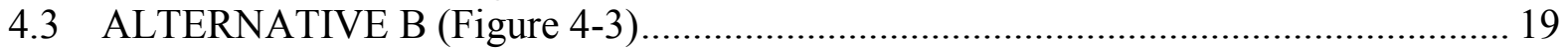

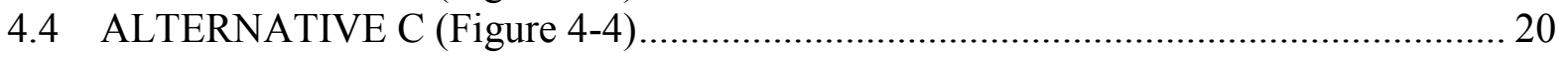

4.5 ALTERNATIVE D (Figure 4-5) ......................................................................... 21

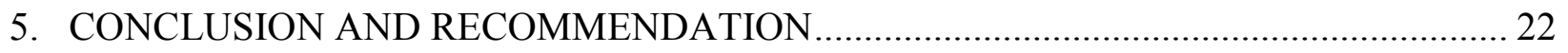

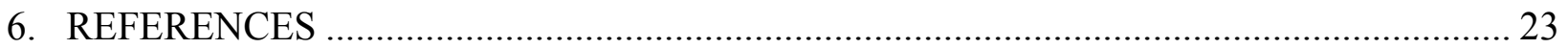

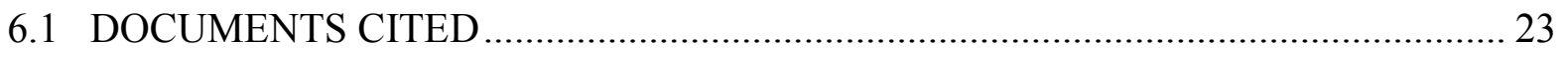

6.2 CODES, STANDARDS, REGULATIONS, AND PROCEDURES …………….......... 24 
PREDECISIONAL STUDY

INTENTIONALLY LEFT BLANK 


\section{FIGURES}

Page

3-1. A Comparison of Thermal Power of Average PWR Assemblies (Ryman 2002c)................. 6

3-2. Function Analysis of Repository Thermal Controls ......................................................... 9

3-3. Drift Pitch for 26 Year Old Fuel................................................................................ 12

3-4. Drift Pitch vs WP Spacing for 15 Year Fuel with 63\% Staged For 27 Years ....................... 13

3-5. Drift Pitch vs WP Spacing w/Staging of 20 Years PWR ave $=6.94 \mathrm{~kW} \ldots \ldots \ldots \ldots \ldots \ldots \ldots \ldots \ldots \ldots . . . . .14$

3-6. Relationship between Staging, WP Spacing, and Ventilation Duration with $70 \%$ eff

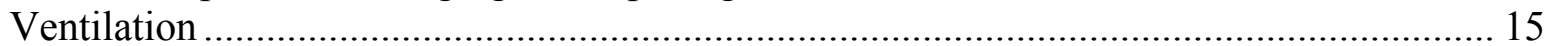

3-7. Ventilation Duration with Drift Pitch of 81 Meters .............................................................. 16

4-1. Thermal Operating Methodology for the Null Alternative ................................................ 17

4-2. Thermal Operating Methodology for Alternative A........................................................ 18

4-3. Thermal Operating Methodology for Alternative B ………………………....................... 19

4-4. Thermal Operating Methodology for Alternative C.......................................................... 20

4-5. Thermal Operating Methodology for Alternative D............................................................. 21 
PREDECISIONAL STUDY

\section{INTENTIONALLY LEFT BLANK}




\section{TABLES}

Page

2-1. Bounding CSNF Characteristics for SYFF5 to 63,000 MTHM ……................................... 5

3-1. Comparison of Average Assembly Properties at Repository Arrival................................... 5 
PREDECISIONAL STUDY

\section{INTENTIONALLY LEFT BLANK}




\section{ACRONYMS AND ABBREVIATIONS}

BSC Bechtel SAIC Company, LLC

BWR boiling water reactor

CRWMS Civilian Radioactive Waste Management System

CSNF commercial spent nuclear fuel

DEIS Draft Environmental Impact Statement

DOE U.S. Department of Energy

FEIS Final Environmental Impact Statement

LTOM Low Temperature Thermal Operating Mode

MGR Monitored Geologic Repository

MTHM metric tons of heavy metal

PDD Project Description Document

PWR pressurized-water reactor

SNF spent nuclear fuel

SYFF5 strict youngest fuel first five years old

WP waste package

WS waste stream 
PREDECISIONAL STUDY

\section{INTENTIONALLY LEFT BLANK}




\section{INTRODUCTION}

\subsection{PURPOSE}

The purpose of this document is to provide decision-makers with a thermal operating methodology that will illustrate potential for flexible thermal operation as the repository. A flexible thermal methodology is defined as a process that will allow management of the thermal energy density within the repository horizon for any waste stream (WS) which conforms to the Waste Acceptance System Requirements Document (DOE 1999a). The focus of this study is to enable repository thermal management at low temperature operations and provide operational parameters for varying the repository's operating temperature. The present study examines operational variations necessary to limit the peak, postclosure waste package surface temperature to 85 degrees Celsius.

\subsection{BACKGROUND}

BSC was directed by the Technical Direction Letter, "Technical Direction to Bechtel SAIC Company, LLC, Contract Number DE-AC08-01RW12101; TDL No. 02-003” (Waisley 2001) directed Bechtel SAIC Company, LLC (BSC) to complete Modular Design Implementation System Evaluation for License Application (BSC 2002a). This study will recommend repository design solutions, under constrained funding, to support receipt and/or emplacement of any or all of the following: commercial spent nuclear fuel (CSNF), high-level radioactive waste, U.S. Department of Energy (DOE)-managed spent nuclear fuel (including naval SNF), and immobilized plutonium (if available), as soon as practicable, but beginning no later than 2010 . From the possible design solutions, a recommended approach will be determined to support a management decision on the preliminary design for license application.

Recent analysis (Yucca Mountain Science and Engineering Report, (S\&ER) p. 2-21 [DOE 2001]) indicates that performance advantages may exist if the post-closure repository temperature (drift wall) remains below the boiling point of water. Concerns regarding material corrosion indicate a temperature for the WP surface to be less than 85 degrees Celsius might improve WP performance (DOE 2001, p. 3-21). In addition, recent WS forecasts (Ryman 2002b) expect the average CSNF assembly arriving at the repository to be hotter than the previously used 26-year-old average fuel due to higher average burn-up and enrichment and younger average age, thus requiring different loading or ventilation strategies.

\subsection{SUMMARY OF ANALYSIS}

The primary tasks associated with this study are as follows:

- Identify and analyze repository operations for thermal management

- Assess the sensitivity to thermal operating parameters

- Develop thermal operating scenarios corresponding to possible repository design alternatives

- Evaluate the thermal operating scenarios 
- Document the results

A functional analysis of operating methodologies was performed to determine those combinations of processes that meet the functional and regulatory criteria for repository operations.

Thermal management strategies were developed and evaluated against criteria and goals for repository operations. The WS scenario used is the most conservative scenario consistent with the ongoing study National Transportation Options for the Modular Design Implementation System Evaluation for License Application (BSC 2002b). At the time of this writing, the most conservative WS scenario is the strict youngest fuel first five years old (SYFF5) (Gillespie 2002). The average WS properties for this scenario were developed as input to a number of 2-D calculations representing potential thermal management strategies. These calculations confirm the viability of those strategies for use with current WS projections. Particular emphasis is placed on meeting the LTOM criteria (WP surface temperature $\leq 85$ degrees Celsius) while providing repository managers with operational parameters for adjusting the repository's operating temperature.

\subsection{QUALITY ASSURANCE}

This technical product was prepared using AP-3.11Q, Technical Reports, as guidance. The report has been determined not to be quality affecting in accordance with the activity evaluation report, Technical Work Plan for Subsurface Design FY 02 Work Activities - Design Requirements and Re-Evaluation of Design Concepts (BSC 2001), Addendum C, p. C2. Therefore, this study is not subject to the requirements of the Quality Assurance Requirements and Description document (DOE 2000).

The control of the electronic management of information is in accordance with the technical work plan for this task (BSC 2001, p. B9). Graphs, tables, and figures in this document were created in Word, Excel, or VISIO 4 Drawing.

In accordance with AP-SI.1Q, Software Management, Section 2.1.1, Microsoft (MS Excel 97 SR-2) is an exempt software used for spreadsheet application. In accordance with Section 2.1.2 of AP-SI.1Q, VISIO 4 Drawing is an exempt application used for visual display.

\section{ASSUMPTIONS}

\subsection{RECEIPT DATE}

The design shall support waste receipt as soon as practicable, but no later than 2010 (Waisley 2001 p. 1).

\subsection{TYPE OF WASTE RECEIVED}

The repository design shall support emplacement of any or all of the following: commercial spent nuclear fuel (CSNF), high-level radioactive waste (HLW), DOE managed spent nuclear fuel (DSNF), and immobilized plutonium (if available) (Waisley 2001 p. 1). This study uses the hotter (SYFF5) fuel for pressurized-water reactor (PWR)/boiling water reactor (BWR) 
assemblies and previous WS (26-year-old fuel) information to calculate the average WP heat load.

\subsection{WASTE EMPLACEMENT}

The WS considered in this study is the SYFF5 (Gillespie 2002). The total number of WPs and types are taken from the Monitored Geologic Repository Project Description Document (PDD), Table 5-5 (Curry 2001).

As a minimum, the initial emplacement rate shall support the subsurface performance confirmation and test facility (Waisley 2001, p. 2).

\subsection{REPOSITORY DESIGN AND OPERATIONS ASSUMPTION BOUNDS}

Repository operations assumptions shall be bounded by values assumed in the Draft Environmental Impact Statement for a Geologic Repository for the Disposal of Spent Nuclear Fuel and High-Level Radioactive Waste at Yucca Mountain, Nye County, Nevada. (DEIS) (DOE 1999b) (including Supplements). Any consideration which is outside the bounds of the DEIS would require revision of the DEIS and is beyond the direction provided (Waisley 2001, p. 2).

\subsection{TOTAL WASTE QUANTITY}

The operations of the repository will be based on a capacity of 70,000 metric tons of heavy metal (MTHM) (63,000 MTHM CNSF, 7,000 MTHM DSNF), but shall not preclude receipt and emplacement of up to the maximum waste quantity described in the DEIS (DOE 1999b). This direction was provided in Waisley 2001, p. 2.

\subsection{TRANSPORTATION CONSIDERATIONS}

Repository thermal operations shall be integrated with the national and Nevada transportation system. This assumption reflects the technical direction from Waisley 2001, p. 2.

\subsection{BASIC REPOSITORY DESIGN}

The basic repository design shall include WPs loaded horizontally into emplacement drifts. The WP is a two-layer, right cylinder consisting of a stainless steel inner shell for strength and Alloy 22 outer shell for corrosion resistance. The actual dimensions vary with the different types of WPs. WP numbers and dimensions are taken from the PDD, Table 5-5 (Curry 2001).

\subsection{PHASED APPROACH TO IMPLEMENTATION}

Because of various restraints imposed on the design/construction of the repository, the actual implementation (including construction, waste receipt, and waste emplacement) of the repository shall be able to accommodate a phased approach. 
The phased approach consists of:

- Modular design of the surface facilities to allow receipt and processing of the waste without all of the facilities constructed.

- Staged repository development of the underground emplacement area, which would allow simultaneous emplacement of waste with construction of additional emplacement drifts.

The need for a phased approach is driven by anticipated funding constraints and is consistent with the direction provided in Waisley 2001.

\subsection{DESIGN BASIS WASTE STREAM}

The incoming WS is based on the first 70,000 MTHM of the entire waste inventory (63,000 MTHM CSNF and 7,000 MTHM DSNF). The selection algorithm for CSNF assumes that fuel will be shipped in strict age order, proceeding from youngest to oldest, beginning with 5-year-old fuel (Gillespie 2002). The bounding characteristics for the CSNF WS are shown in Table 2-1. Additional information on the WS will be obtained from the results of BSC 2002b.

\subsection{SITE RECOMMENDATION (SR) PARAMETERS}

The SR in-drift parameters of Drift Spacing, Drift Diameter and emplacement configuration of the WPs will be used in this study.

\subsection{THERMAL MODELING}

The average heat load of all the WPs, when $63 \%$ of the waste was aged for 27 years is $8.41 \mathrm{~kW} / \mathrm{Pkg}$, Non aged fuel results in an average heat load of $12.48 \mathrm{~kW} / \mathrm{Pkg}$. The ANSYS calculations used for this study were based on the loading of the entire repository with fuel which was decayed using the commercial fuel decay curves shifted in time. This utilization of the average heat load per packages represents the entire inventory of waste types such as DOE SNF, HLW, etc.

NOTE: For this study, the ventilation efficiency was varied from $50 \%$ to $80 \%$. A recent revision to the ventilation analysis and model report reveals that the ventilation efficiency increases with time, reaching as much as $95 \%$ for 300 years of ventilation. 
Table 2-1. Bounding CSNF Characteristics for SYFF5 to 63,000 MTHM (Gillespie 2002)

\begin{tabular}{|l|l|l|l|l|l|l|}
\hline \multirow{2}{*}{ Parameters } & \multicolumn{3}{c|}{ BWR } & \multicolumn{2}{c|}{ PWR } \\
\cline { 2 - 7 } & Minimum & Average & Maximum & Minimum & Average & Maximum \\
\hline $\begin{array}{l}\text { Age (years from core } \\
\text { discharge) }\end{array}$ & 5 & 12.7 & 53 & 5 & 12.4 & 56 \\
\hline Enrichment (\%) & 0.7 & 3.9 & 5.0 & 0.3 & 4.4 & 5.0 \\
\hline Burnup (GWd/MT) & $0.0^{*}$ & 45.0 & 66.0 & 2.0 & 49.0 & 71.0 \\
\hline
\end{tabular}

*NOTE: No "0" values were used to calculate the average WP thermal load.

\section{REPOSITORY THERMAL MANAGEMENT}

\subsection{THE WASTE STREAM THERMAL LOAD}

The bounding WS selected for this study has substantially different thermal characteristics from the previously used 26-year-old fuel. A comparison of the SYFF5 WS with the more widely used Case A, 63,000 MTHM WS found in Waste Package and Source Terms for the Commercial 1999 Design Basis Waste Streams (CRWMS M\&O 2000b) is given in Table 3-1. This study used an average heat load of $8.41 \mathrm{~kW} /$ package for the SYFF5 case. This is based on $63 \%$ of the SYFF5 fuel being staged for 27 years (Ryman 2002a). The average heat load for the SYFF5 not aged case is $12.48 \mathrm{~kW} /$ Package (Ryman 2002b).

NOTE: Twenty-seven years is based on The Nuclear Waste Policy Act, As Amended, With Appropriations Acts Appended (DOE 1995) allowance to close the repository within 50 years after first waste emplacement and 23 years to emplace the waste.

Table 3-1. Comparison of Average Assembly Properties at Repository Arrival

\begin{tabular}{|l|l|l|l|l|}
\hline \multicolumn{1}{|c|}{ Waste Stream } & \multicolumn{1}{|c|}{ Fuel Type } & \multicolumn{1}{|c|}{ Age (years) } & \multicolumn{1}{c|}{ Burnup (GWd/t) } & \multicolumn{1}{c|}{ Enrichment (\%) } \\
\hline $\begin{array}{l}\text { Case A, 63,000 } \\
\begin{array}{l}\text { MTHM (CRWMS } \\
\text { M\&O 2000b) }\end{array}\end{array}$ & PWR & 23.1 & 41.2 & 3.75 \\
\cline { 2 - 5 } & BWR & 22.7 & 33.6 & 3.03 \\
\hline $\begin{array}{l}\text { SYFF5 (Gillespie } \\
\text { 2002) }\end{array}$ & PWR & 12.4 & 49.0 & 4.40 \\
\cline { 2 - 5 } & BWR & 12.7 & 45.0 & 3.9 \\
\hline
\end{tabular}

A visual representation of the thermal load comparison for PWR fuel assemblies can be seen in Figure 3-1. This figure shows the ratio of thermal power for PWR assemblies in the old and new WSs. The shifted WS curve shows the increased thermal load due to burnup and enrichment only. The new WS (SYFF5-PWR) has been shifted to be the same age as the old WS (Case A 63k-PWR). 


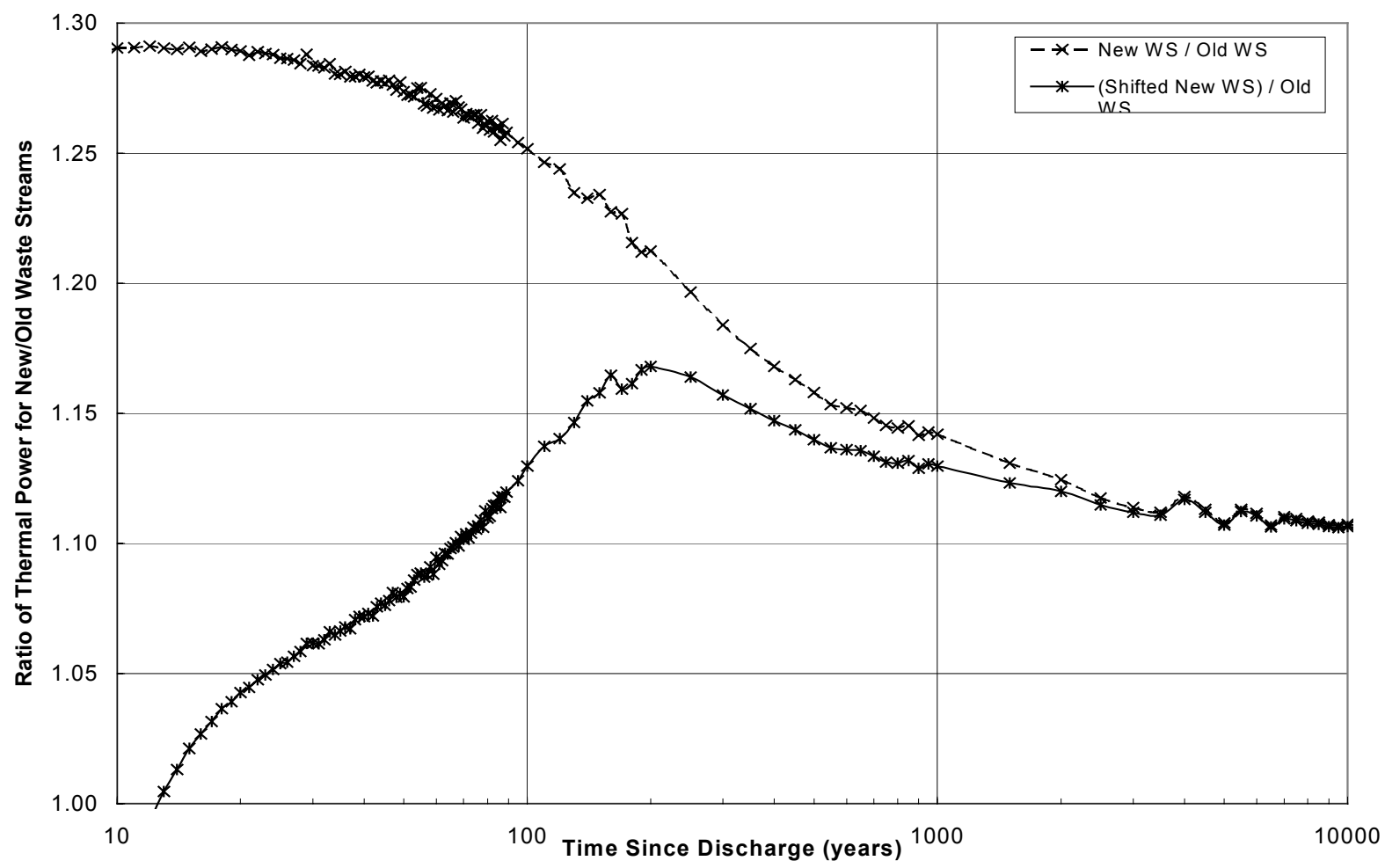

Figure 3-1. A Comparison of Thermal Power of Average PWR Assemblies (Ryman 2002c)

This hotter WS will demand a new approach to repository thermal management, specifically a flowchart of thermal management options in which each assembly's thermal power, at repository arrival, defines for it a specific thermal management plan.

\subsection{THE CONTROL OF REPOSITORY TEMPERATURE}

The temperature criteria for repository performance apply only to the post-closure time period. The primary reason for restricting the WP surface temperature is because of the effects of high temperatures near boiling on Alloy 22 corrosion. At temperatures of 85 degrees Celsius or less, and/or relative humidity of $50 \%$ or less, Alloy 22 is less susceptible to corrosion (S\&ER [DOE 2001 p.3-21]). During the pre-closure period, the drifts will be monitored and any problems with WP performance can be remedied, therefore all repository temperature controls, applied in the pre-closure time period, are meant to affect a change in the postclosure performance.

The key to controlling the peak temperature, at any point within the repository, is to control the thermal energy density within the repository horizon of the mountain. Thermal energy density is just another way of saying temperature. However, it allows for visualizing temperature as the magnitude of energy per unit volume with a constant specific heat. The higher the energy density within a given volume the higher the temperature, adjusted of course, for the specific heat of the material the energy is being stored in.

If there were hot spots within the repository, then the thermal energy density would appear lumpy, assuming that the specific heat of each geo-stratigraphic layer is homogenous. The low conductivity of the host rock within Yucca Mountain, while causing other thermal management 
challenges, has the quality of rapidly damping and smoothing the thermal energy density. This smoothing quality of the host rock confines most lumpiness in the thermal energy density to the drifts themselves.

NOTE: For this study, lumpiness is the variation in temperatures that will exist because the repository heat load was simulated based on an average WP and average heat load/package. This means that there will be a variation around the average and therefore the thermal density will vary.

The temperature of the WP has a great effect on the corrosion susceptibility (DOE 2001, p. 3-21). Perhaps no other surface within the repository will have a greater variance in temperature than the WP. It must be remembered that all calculations for this study are based upon average properties, and use of a conservative WS. There is a distribution of WP surface temperature about the average. The variance of the distribution will depend upon the WP size, drift configuration, ventilation flow rate, and duration of ventilation.

\subsection{GENERAL METHODS FOR CONTROL OF REPOSITORY TEMPERATURE}

All methods of controlling temperature within the repository fall within one of the two following categories. That is, some portion of the thermal energy generated by the WS can be removed before fuel enters the repository, and some portion of the thermal energy generated by the WS can be removed after it enters the repository. The remaining thermal energy must be absorbed by materials within the repository and contributes to thermal energy density, hence, temperature.

\subsubsection{Removing Thermal Energy Before Emplacement}

Thermal energy can be removed from the WS before it enters the repository by staging (or aging) fuel. Staging allows the fuel to decay thermal power, thereby reducing the amount of energy the fuels contribute to the repository temperature. This study considers staging above ground in dry storage casks and below ground in staging canisters, within tunnels far enough away from the repository horizon.

\subsubsection{Distributing Thermal Energy During Emplacement}

Spreading the thermal energy over a greater area or decreasing the WP thermal output reduces the mean temperature within the repository. The following are ways to distribute the energy: 1) spacing the WPs to ensure a specific linear heat load; 2) using smaller WPs; 3) de-rating the current WPs (which is defined as loading less than the maximum number of assemblies in a given WP [i.e., placing 16 assemblies in a 21 PWR WP]); 4) blending hot and cool assemblies into a single WP to ensure a specified maximum thermal power; and 5) adjusting the area's mass loading by adjusting the drift spacing, will distribute the thermal loading. This study considers four of the options to managing repository temperature.

NOTE: De-rating of a WP has an advantage for thermal considerations as the thermal power per WP is reduced while maintaining the WP surface area the same. This effect would lower the WP surface temperature, thereby decreasing the corrosion susceptibility more than using a smaller WP due to the surface area heat transfer effects. It is noted that the cost would be greater for a de-rated WP than using a smaller WP. 


\subsubsection{Removing Thermal Energy After Emplacement}

A fraction of the thermal energy generated by the WPs, after they are emplaced, can be removed from the repository by means of ventilation. Both forced and natural ventilation can be used to remove energy from WP surfaces. The fraction of energy removed relates to the efficiency of ventilation and the flow rate. Predicting the natural ventilation efficiency and flow-rate, presents an interesting challenge; therefore, this study relies on forced ventilation with varying efficiency to determine appropriate alternatives to repository thermal operating methodology.

\subsection{FUNCTIONAL ANALYSIS OF THERMAL OPERATIONS}

\subsubsection{The Functional Analysis System Technique (FAST) Diagram}

Figure 3-2 is a diagram of the repository thermal operating functions showing the available methods for flexibly managing repository temperature. The three general methods for controlling repository temperature are shown along with the more specific methods of each.

None of the general methods are sufficient for achieving the low temperature operating criteria for the repository by itself. For this reason, all the alternatives to the flexible management of temperature will involve at least two of the general methods. Ventilation and variable WP spacing were required to reach LTOM goals for every alternative evaluated.

This function diagram illustrates how WP surface temperature criteria can be achieved with a flexible thermal operations methodology. 


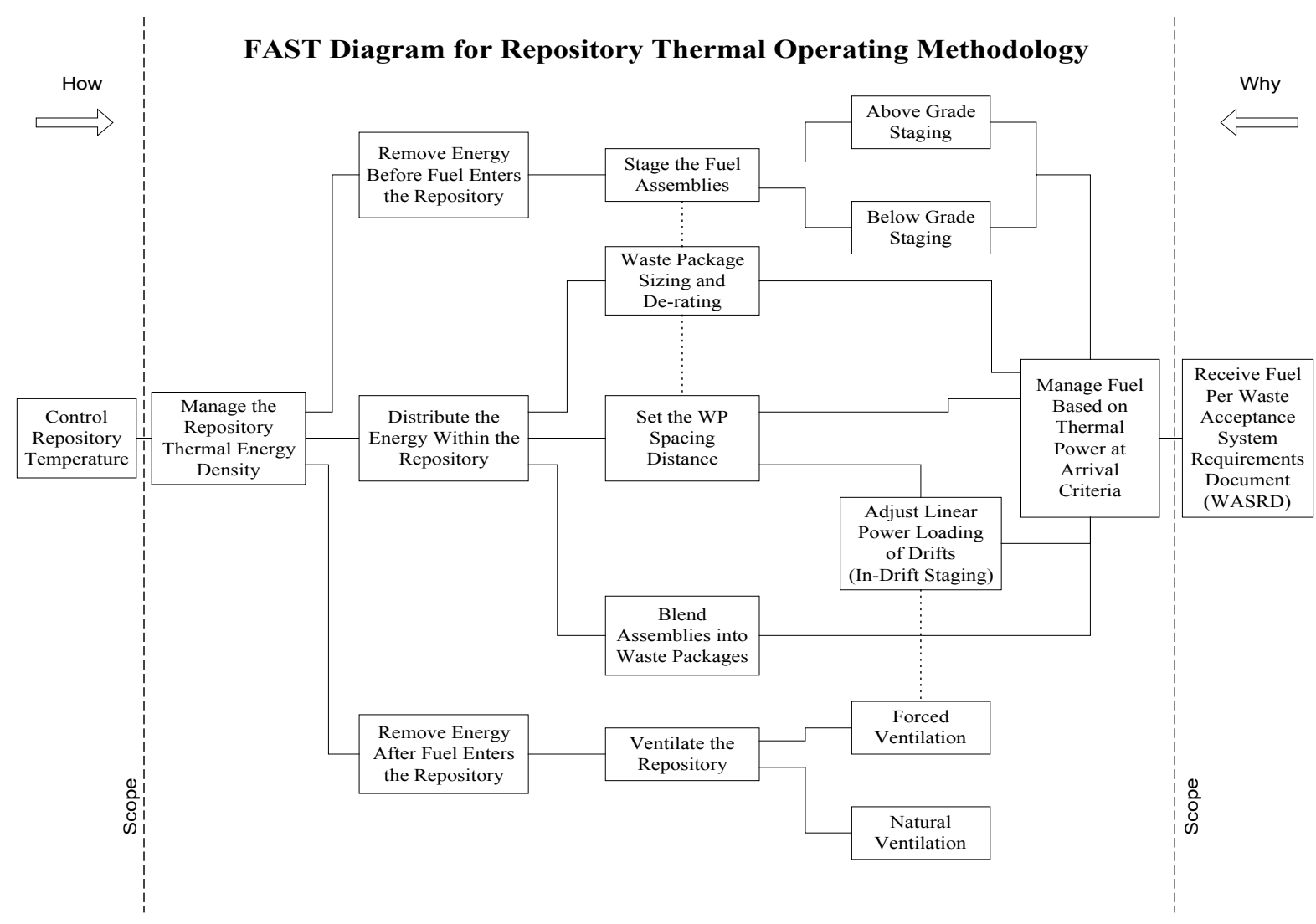

Figure 3-2. Function Analysis of Repository Thermal Controls

\subsubsection{The Thermal Criteria and Thermal Goals}

- Allow repository operation at LTOM while maintaining options for higher temperature operation (Waisley 2001, p. 1).

- The Final Environmental Impact Statement for a Geologic Repository for the Disposal of Spent Nuclear Fuel and High-Level Radioactive Waste at Yucca Mountain, Nye County, Nevada (FEIS) (DOE 2002) specifies the "DOE would consider aging as much as two thirds of the commercial SNF during a 50 year period." (NOTE: For this study "aging" and "staging" are synonymous.)

- The FEIS (DOE 2002) specifies the range of ventilation as "up to 300 years of post-emplacement ventilation."

\subsubsection{Functional Analysis Limitations}

- This study utilizes $88 \mathrm{~km}$ of emplacement drift. It is recognized that another more recent drift layout, which utilizes 5 -segment design, has $97.56 \mathrm{~km}$ (Linden 2002) of emplacement drift. This more recent layout has some uncertainty in the longer emplacement drift due to drift length exceeding 600 meters and different rock strata. 
Therefore, for this study, the $88-\mathrm{km}$ of usable emplacement drift was utilized; this represents about $90 \%$ of the available drift length for conservatism.

- 2D ANSYS (version 5.4) thermal calculation results were used.

\subsection{OPERATIONAL PARAMETERS}

\subsubsection{WP Spacing, Drift Spacing, Ventilation Duration (With SYFF5 Fuel)}

It is assumed that repository operations will utilize a variable WP spacing based on each package's thermal power. In a variable WP spacing repository, the average WP spacing for the 70,000 MTHM inventory is an operational parameter used to adjust the repository temperature.

A sensitivity analysis (Anderson 2002) of WP spacing shows that increasing the WP spacing can make substantial temperature difference (see Figures 3-3, 3-4, and 3-5). However, limitations to the physical size of the repository and the number of WPs places a maximum average WP spacing of 2.83 meters. This limit is based on $88 \mathrm{~km}$ of total useable emplacement drift (Linden 2002) and 11,184 WPs. WP spacing of 2.83 meters and 11,184 WPs result in a total length of emplacement drift needed of $87,988 \mathrm{~m}$. WP spacing is a closely coupled parameter with ventilation duration and staging. Figure 3-6 shows a plot of the relationship between these three parameters given a WP surface temperature of 85 degrees Celsius and the conservative SYFF5 WS.

WP spacing can be varied, holding the SR design drift pitch (drift spacing) of $81 \mathrm{~m}$, from $0.1 \mathrm{~m}$ to as high as $2.83 \mathrm{~m}$. To maintain WP surface temperature at 85 degrees Celsius and operate at LTOM, it will be necessary to stage the fuel longer, increase the preclosure ventilation period, and possibly verify the ventilation efficiency. All of the parameters can effect the WP temperature after closure of the repository.

The WP spacing can be increased to a certain distance where line loading becomes a point load. For example, WP thermal coupling with 25 years of ventilation is considered to shift from a line load to a point load at approximately $6 \mathrm{~m}$ of WP spacing. (Table 6-22, Series 2, Case 5, p. 80 CRWMS M\&O 2000a). The point loading method can be used in in-drift staging before emplacement.

Drift pitch (spacing) can be varied from as little as $40 \mathrm{~m}$ to as large as $120 \mathrm{~m}$, or more, in the repository footprint. However, to accomplish the small pitch, it will be necessary to stage the fuel longer and or increase the ventilation duration and possibly increase the WP spacing in order to remove residual heat. To reach the 120-m drift spacing would require a new repository layout and evaluation to ensure that there is sufficient emplacement drift length to emplace the 77,000 tons of waste.

The preclosure ventilation period can be varied from as little as 125 years to as long as 300 years, depending on the age of the fuel, drift pitch, and WP spacing. The shorter ventilation time period will require more aging of the fuel, smaller WPs, larger WP spacing, or cooler fuel. This parameter is within the control of the repository operators and selection of the proper duration and flow rate will have to be guided by the actual properties of the waste upon receipt. 
NOTE: This study held ventilation efficiencies constant at a given percentage of thermal energy removed. It is noted that ventilation efficiencies vary as WP spacing is varied and with time.

A sensitivity analysis (Anderson 2002), see Figure 3-7, of ventilation duration versus WP temperature shows that the dependent variable (WP surface temperature) is not greatly effected by durations greater than 150 years (see Figure 3-7). The diminishing return is due the decay of WP thermal power, combined with lower temperatures within the drifts that mitigate heat transfer to the bulk fluid air stream.

\subsubsection{WP Loading}

Three methods are available to control the WP thermal loading: 1) use smaller packages; 2) size a WP to hold less assemblies and thereby reduce its total thermal power; and 3) use cooler PWR/ BWR assemblies such that their total heat load is reduced.

The effect of lower WP loading is to reduce the heat output, lowering the WP temperature to meet LTOM thermal criteria and reducing the variability in the thermal power output of each package. Reducing variation in the WPs reduces lumpiness in the thermal energy density, and improves the confidence of numerical analysis.

Replacing the 21-PWR WP with the 16-PWR WP will lower the overall average WP thermal load of the repository. However, this option creates an additional 1,396 WPs. This number is created by comparing the following: the total number of PWR assemblies 94,162 (Gillespie 2002), therefore $94,162 / 21=4,489$ and $94,162 / 16=5,885$ and the difference $=1,396$ package. The cost of the increased number of WPs would also have to be considered.

\subsubsection{Staging Effects on Operational Parameters}

Staging the fuel for a period of time reduces the heat load and therefore WP temperature. In Figure 3-3, all of the fuel is 26 years old and a portion of the original heat has been removed through aging. This results in several solutions for the LTOM repository operation and ventilation duration. Staging only some of the fuel for a period of time also has a benefit; with $63 \%$ of the SYFF5 fuel staged for 27 years, the hot fuel average for the entire repository is reduced from $12.48 \mathrm{~kW} /$ package to $8.41 \mathrm{~kW} /$ package (Ryman 2002a). This lower average thermal load results in the repository being capable of being operated in the LTOM mode rather than at a much higher temperature (see Figure 3-4). 


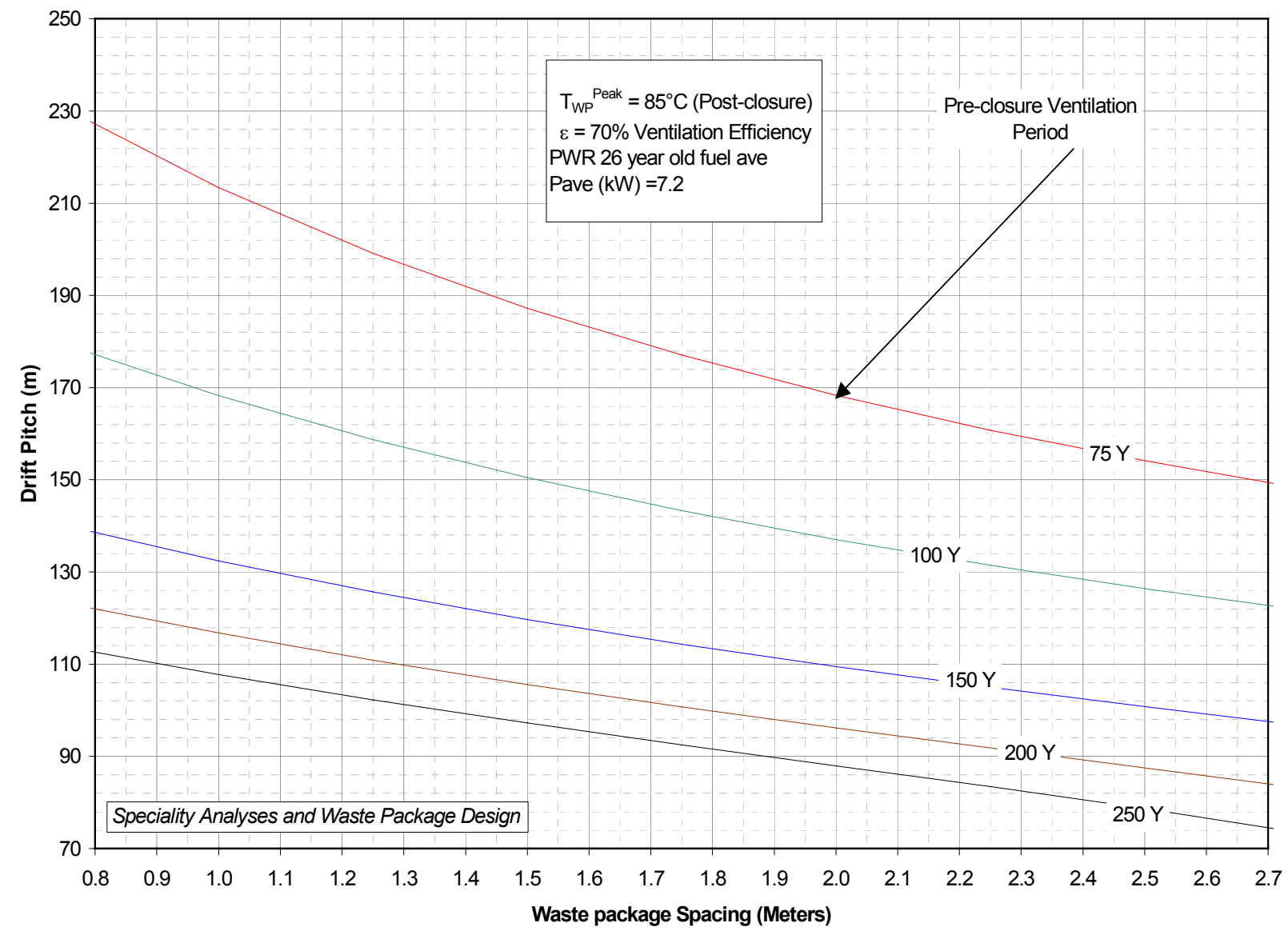

Figure 3-3. Drift Pitch for 26 Year Old Fuel

Figure 3-3 shows that with a drift pitch of $81 \mathrm{~m}$, ventilation efficiency of 70\%, and 26-year-old fuel is very close to the lowest possible limit that can support LTOM (DOE 2001, p. 2-83). With 26-year-old fuel heat load, it would take at least 250 years of preclosure ventilation and a WP spacing of about 2.4 meters to ensure that the WP temperature is 85 degrees Celsius or lower. Further review of Figure 3-3 reveals that if the drift spacing were increased to 90 meters, two solutions would be possible for maintaining the WP surface temperature to 85 degrees Celsius or less. Those solutions are 1) 250 years of ventilation and 1.9 meters WP spacing and 2) 200 years of ventilation with 2.35 meters WP spacing. To obtain a 150 -year ventilation period would require a drift pitch of about 120 meters and WP spacing of $2.7 \mathrm{~m}$. 


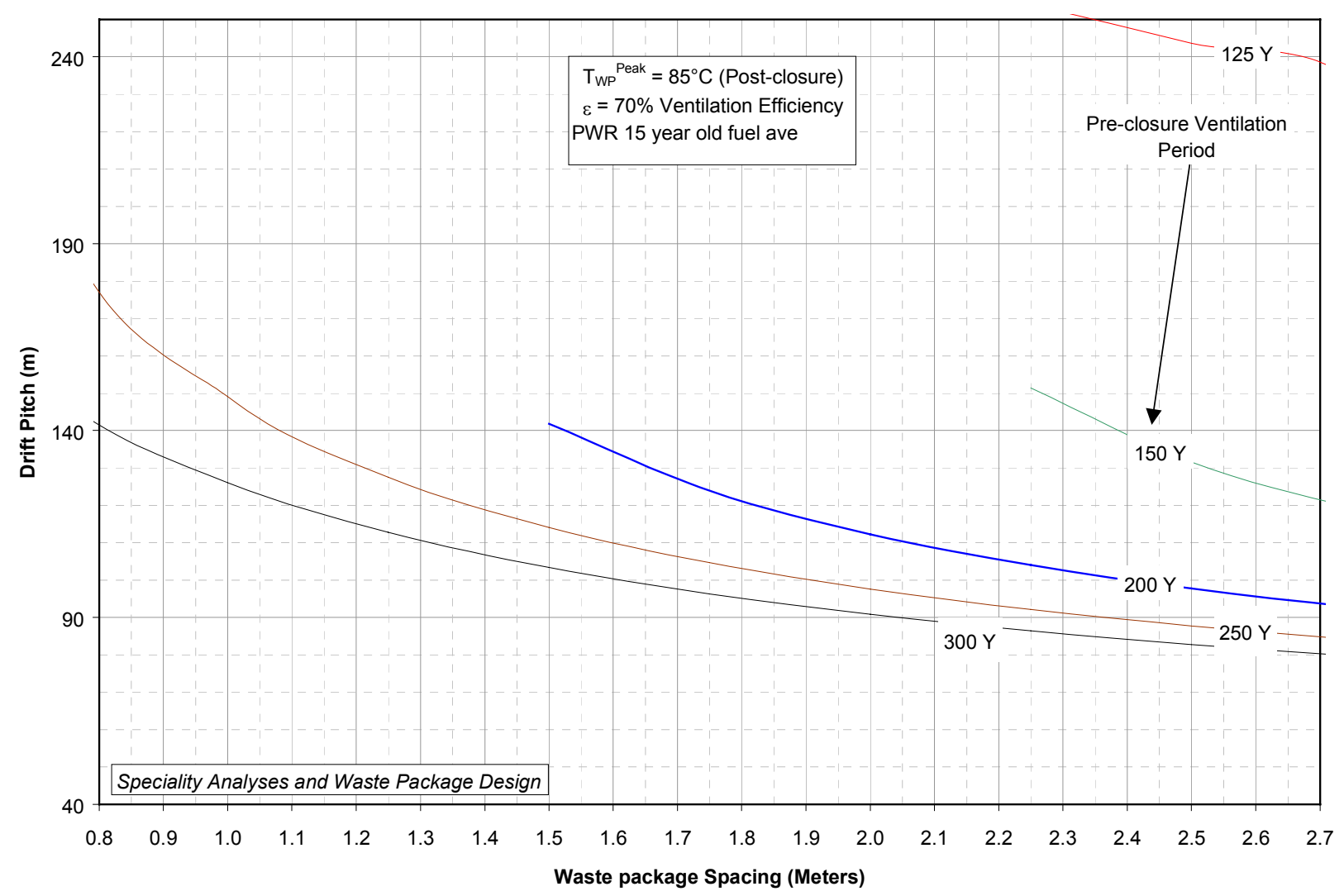

Figure 3-4. Drift Pitch vs. WP Spacing for 15 Year Fuel with $63 \%$ Staged For 27 Years

Analysis of Figure 3-4 (Anderson 2002) reveals that for the assumed WS, maintaining the current drift pitch of $81 \mathrm{~m}$ and LTOM is only possible with 300 years of ventilation and a WP spacing of 2.73 meters, which is very close to the 2.83 -meter maximum spacing to remain within the $88 \mathrm{~km}$ repository. With SYFF5 fuel and 63\% of the fuel Staged For 27 Years heat load, it would take at least 250 years of preclosure ventilation, a drift spacing of $90 \mathrm{~m}$ and a WP spacing of about $2.4 \mathrm{~m}$ to ensure that the WP temperature is 85 degrees Celsius or lower. When the fuel is younger and hotter, it is emplaced and it becomes more difficult to maintain the temperature at 85 degrees Celsius or less. 
Drift Spacing Vs. WP Spacing w/ PWR staged 20 years

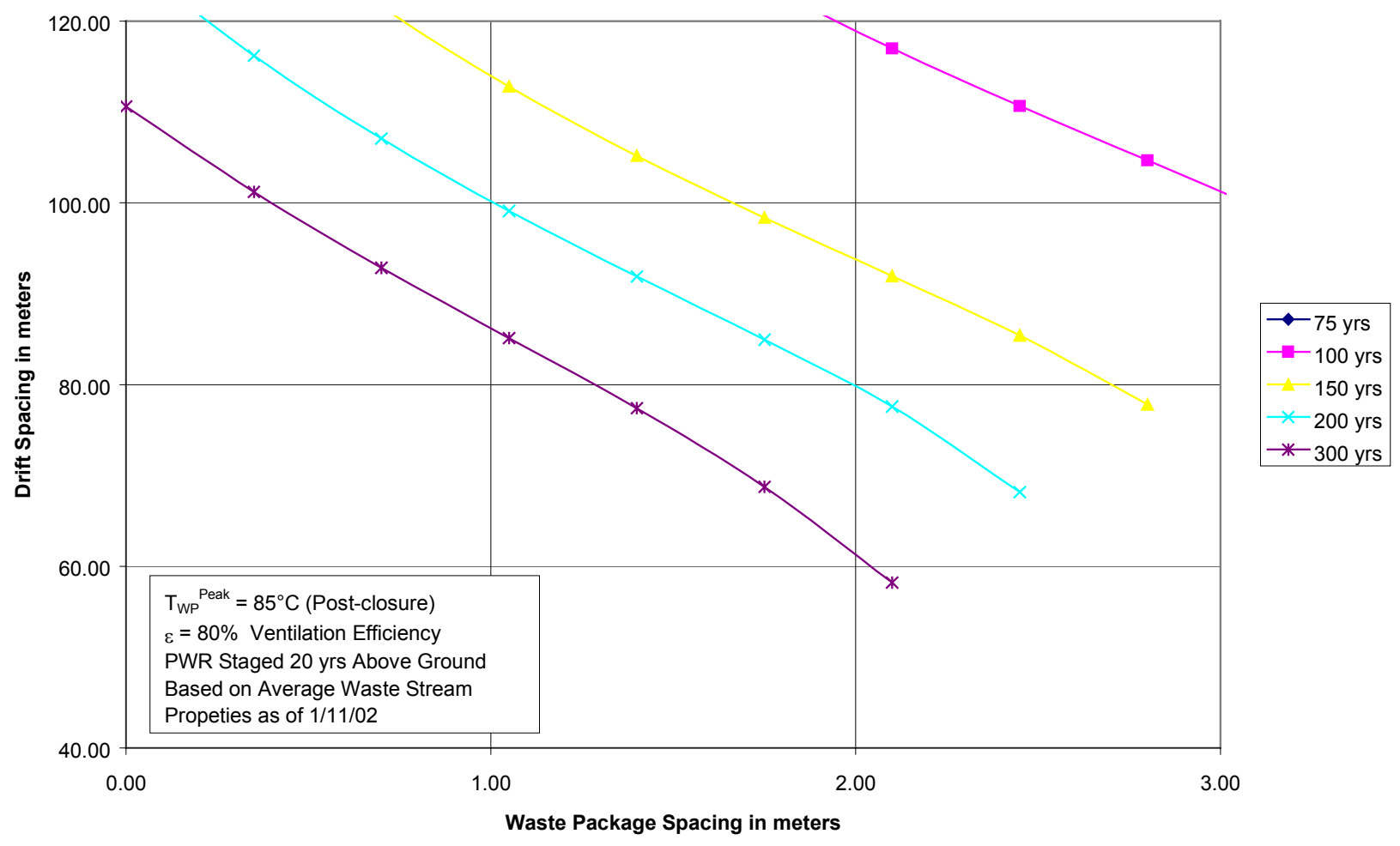

Figure 3-5. Drift Pitch vs. WP Spacing w/Staging of 20 Years $P W R_{a v e}=6.94 \mathrm{~kW}$

Comparing Figure 3-4 to Figure 3-5 (Anderson 2002) shows aging of the fuel and a 10\% increase in ventilation efficiency results in shifting the intersections of the ventilation time, drift spacing, and WP spacing. In Figure 3-4, obtaining an 81-m drift space and 85 degrees Celsius WP surface temperature requires 300 years of ventilation with $2.73 \mathrm{~m}$ of WP spacing. Figure 3-5 shows to obtain 81-m drift spacing and 85 degrees Celsius WP surface temperature, the WP space is decreased to approximately $1.1 \mathrm{~m}$. It is also possible to ventilate for 200 years with a WP spacing of approximately 1.9 meters.

Analysis of Figure 3-6 (Anderson 2002) reveals that the SYFF5 fuel must be partially aged and ventilated for a significant time to support LTOM. For example to minimize the ventilation period to about $100+$ years, with 40,000 MTHM staged for 27 years requires a WP spacing in excess of 2.5 meters which is near the 2.83 meter WP spacing limit. Aging smaller portions of the fuel (e.g., 20,000 MTHM for 27 years) results in the need to increase the ventilation duration appropriately. If no portion of the fuel is aged, then the WP spacing must be increased to the maximum and ventilation duration to 275-300 years. 
$\underline{\text { PREDECISIONAL STUDY }}$

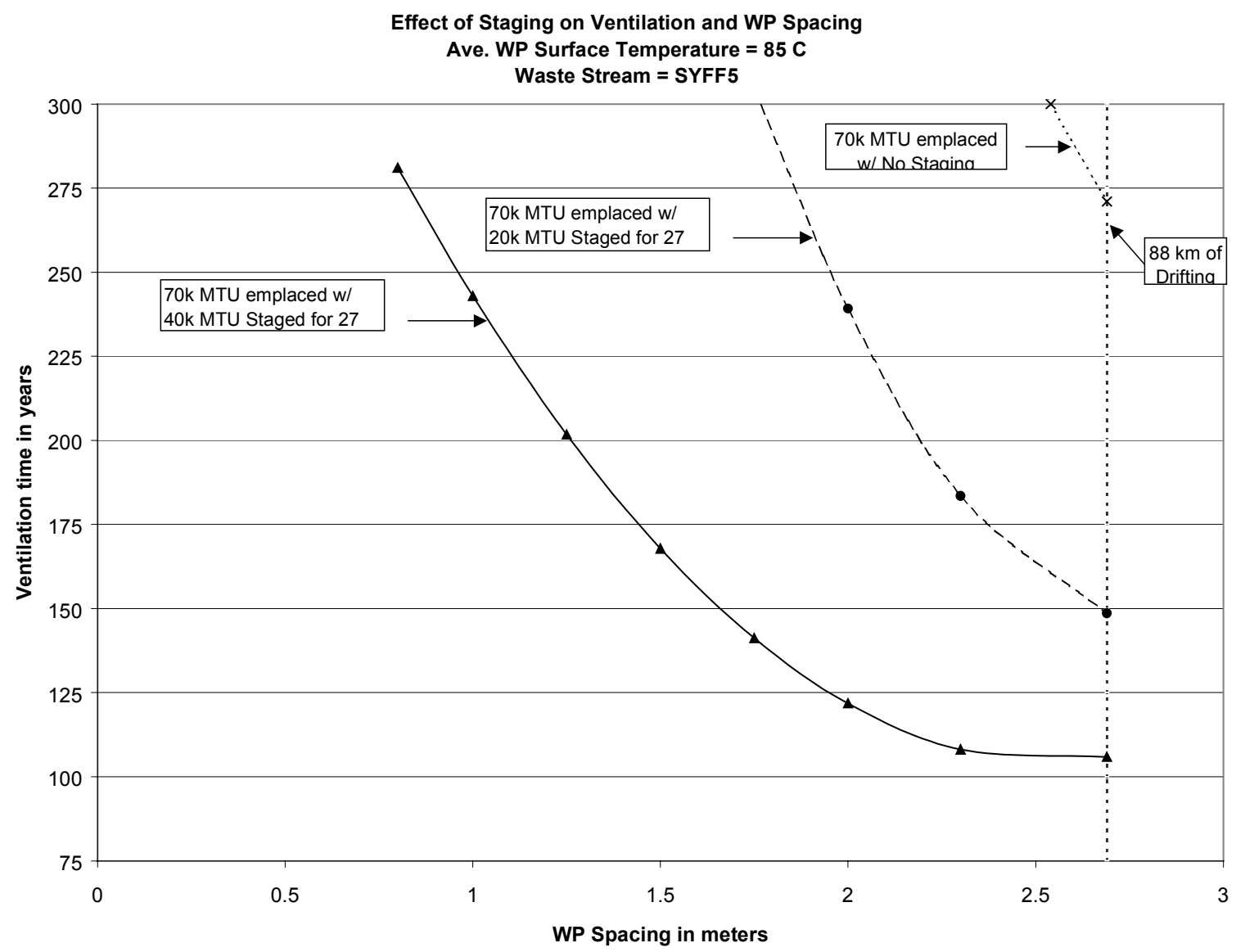

Figure 3-6. Relationship between Staging, WP Spacing, and Ventilation Duration with $70 \%$ eff Ventilation 
Maximum temperature at the surface of the Waste Package - Postclosure period

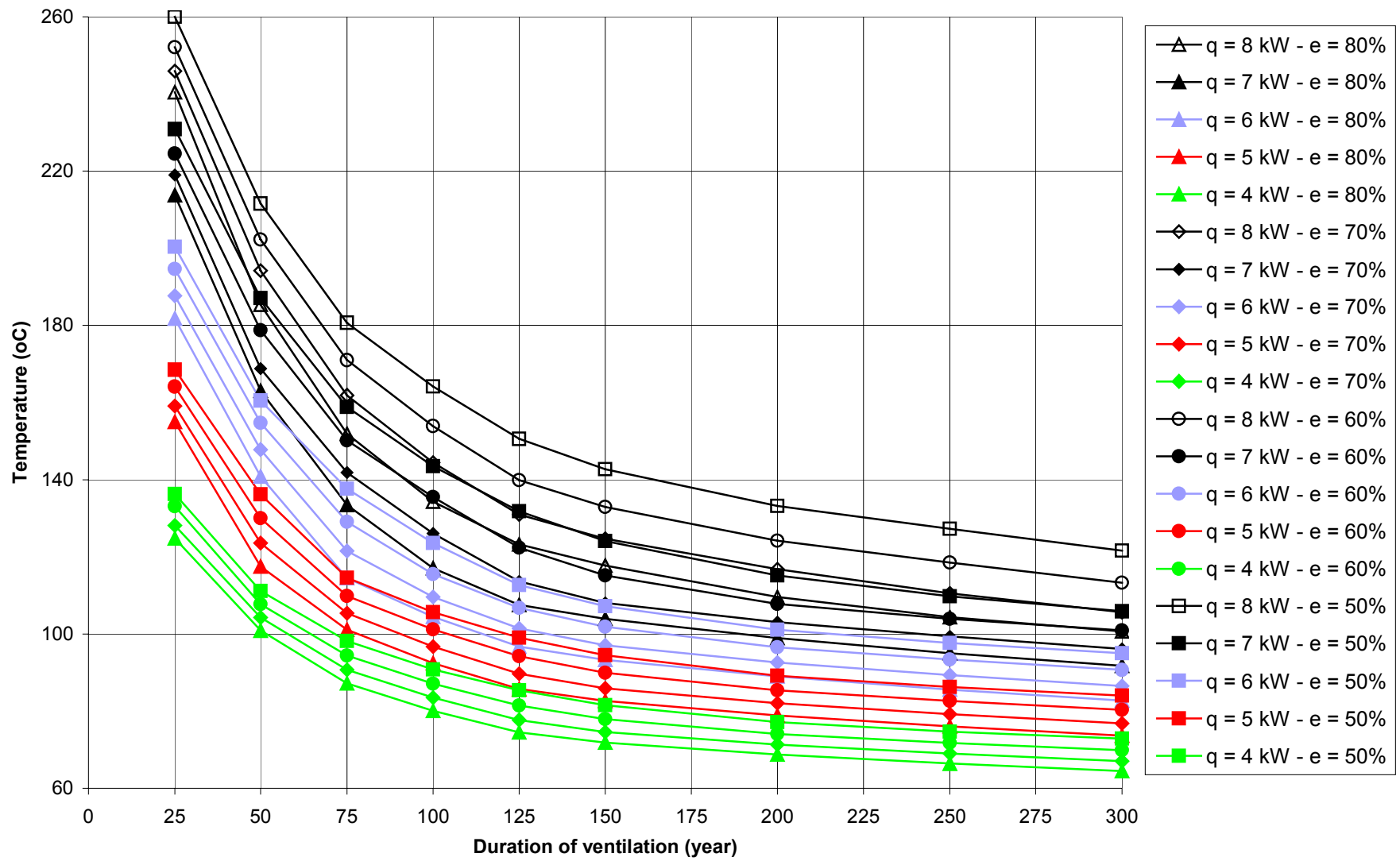

Figure 3-7. Ventilation Duration with Drift Pitch of 81 Meters

\section{THERMAL OPERATIONS METHODOLOGY ALTERNATIVES}

The purpose of this section is to use the information defined in Section 3 and to evolve the repository design to a point that is flexible enough to meet the assumptions listed in Section 2. The output of the effort in Section 3 will be the candidate components of an overall system operations methodology that will assist the repository operators. These candidate components will provide building blocks that can be put together in different ways to form system operations alternatives. These alternatives are shown in the following alternatives graphically. 


\subsection{NULL ALTERNATIVE (FIGURE 4-1)}

The Null Alternative is to leave the current baseline for repository operations unchanged. This alternative maximizes the use of available emplacement drifting and requires extensive use of preclosure ventilation. Figure 4-1 presents a flowchart of repository operations for the Null Alternative.

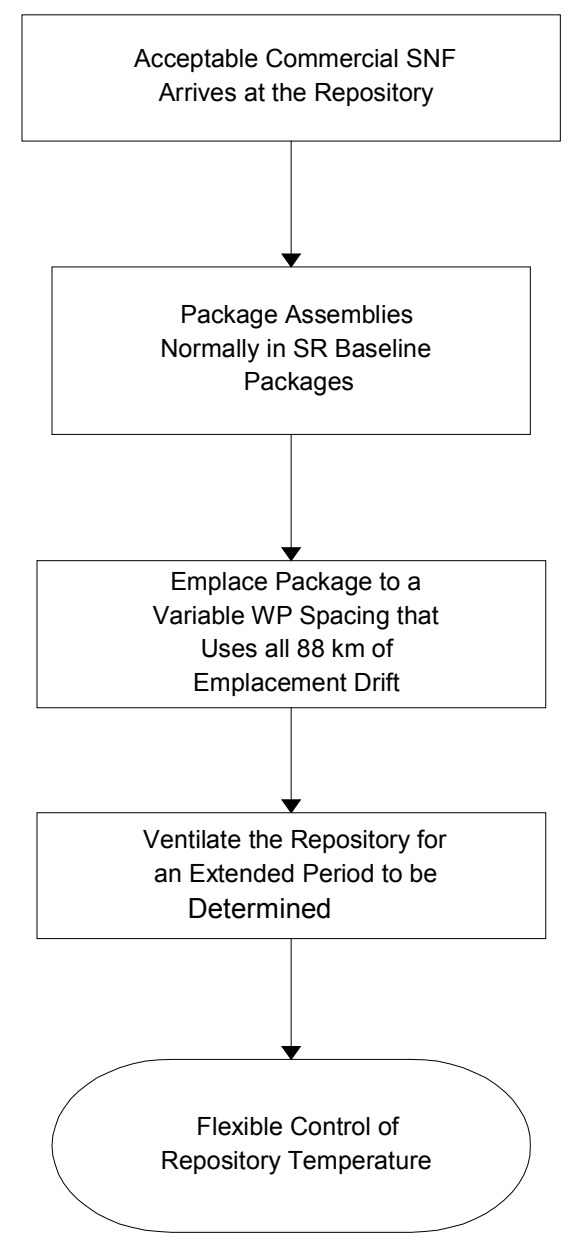

Figure 4-1. Thermal Operating Methodology for the Null Alternative 


\subsection{ALTERNATIVE A (FIGURE 4-2)}

Alternative A utilizes staging and smaller WPs combined with a variable WP spacing and ventilation to achieve flexible repository operations.

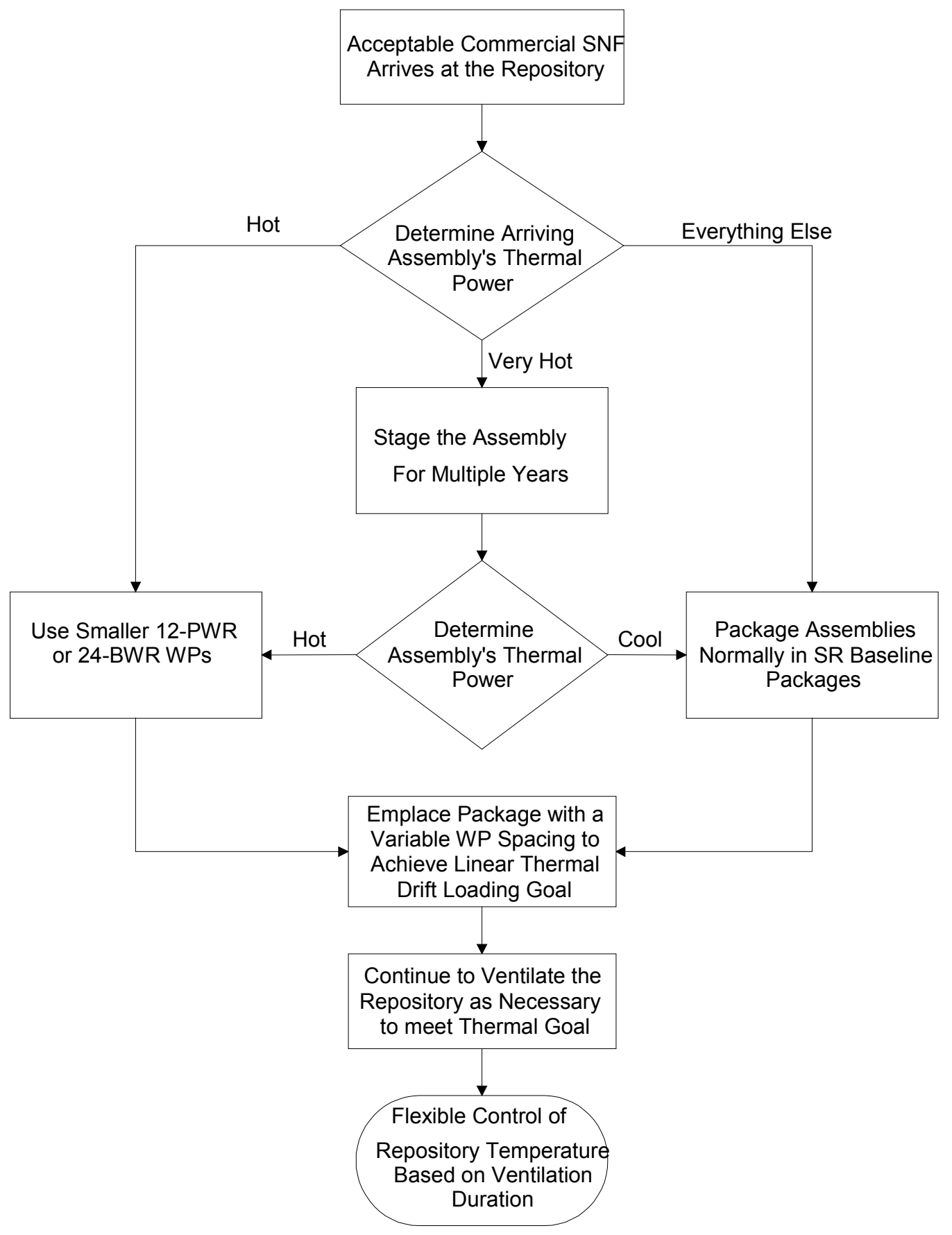

Figure 4-2. Thermal Operating Methodology for Alternative A 


\subsection{ALTERNATIVE B (FIGURE 4-3)}

Alternative B utilizes staging, and without using smaller WPs, combined with a variable WP spacing and ventilation to achieve flexible repository operations.

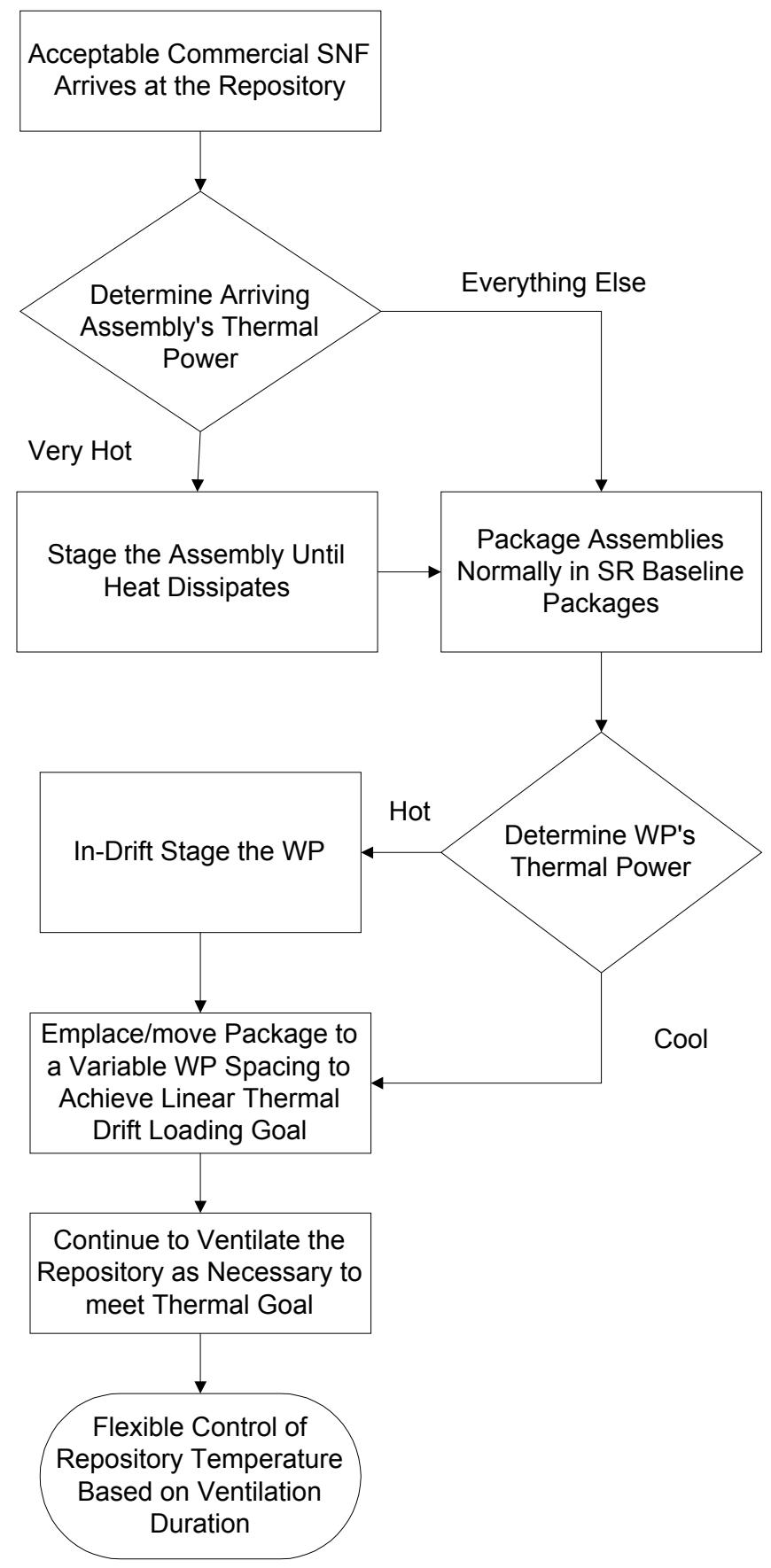

Figure 4-3. Thermal Operating Methodology for Alternative B 


\subsection{ALTERNATIVE C (FIGURE 4-4)}

Alternative $\mathrm{C}$ eliminates staging but uses assembly de-rating combined with a variable WP spacing and ventilation to achieve flexible repository operations.

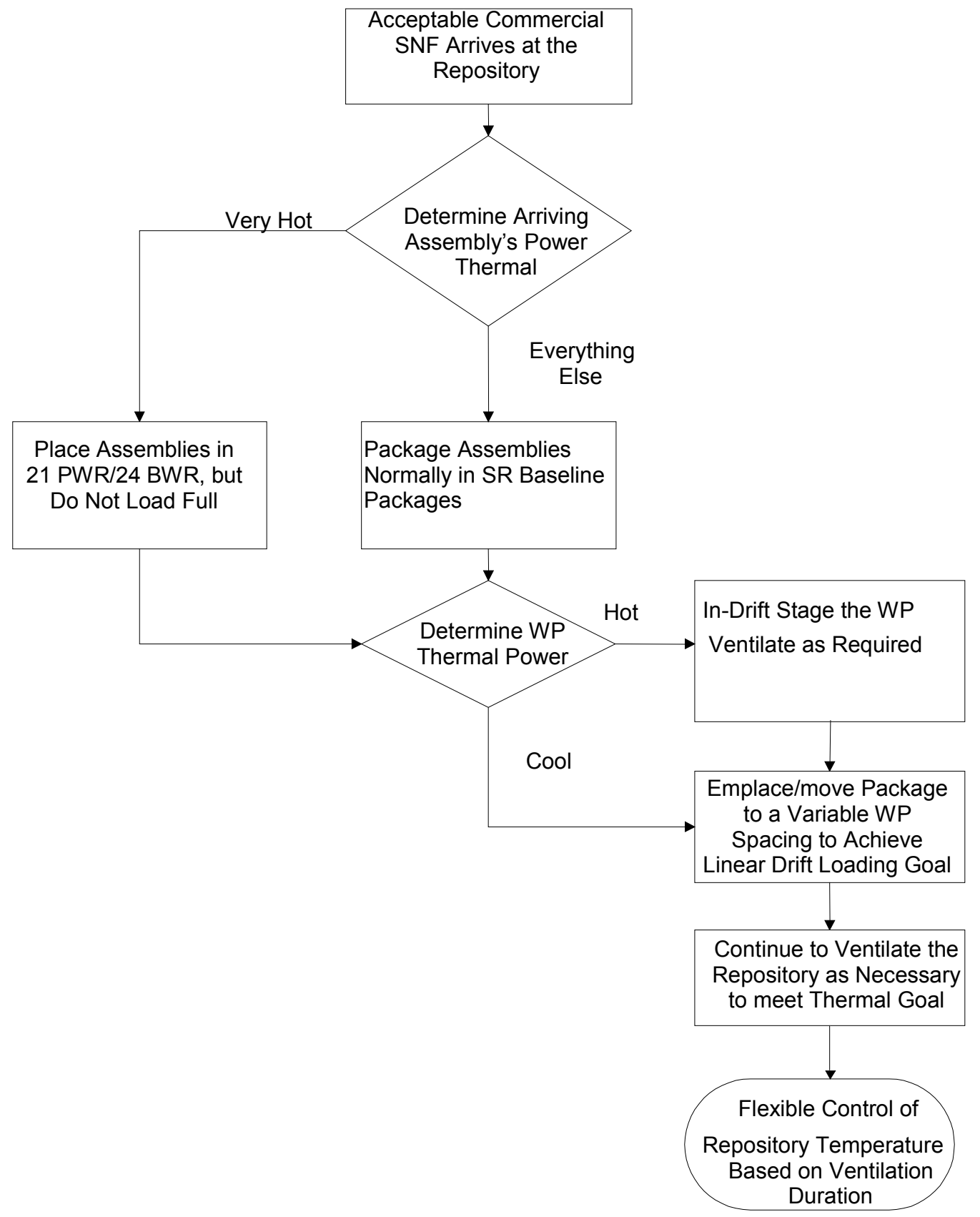

Figure 4-4. Thermal Operating Methodology for Alternative C 


\subsection{ALTERNATIVE D (FIGURE 4-5)}

Alternative D combines all the methods of staging, de-rating, and in-drift staging with varied WP spacing and ventilation.

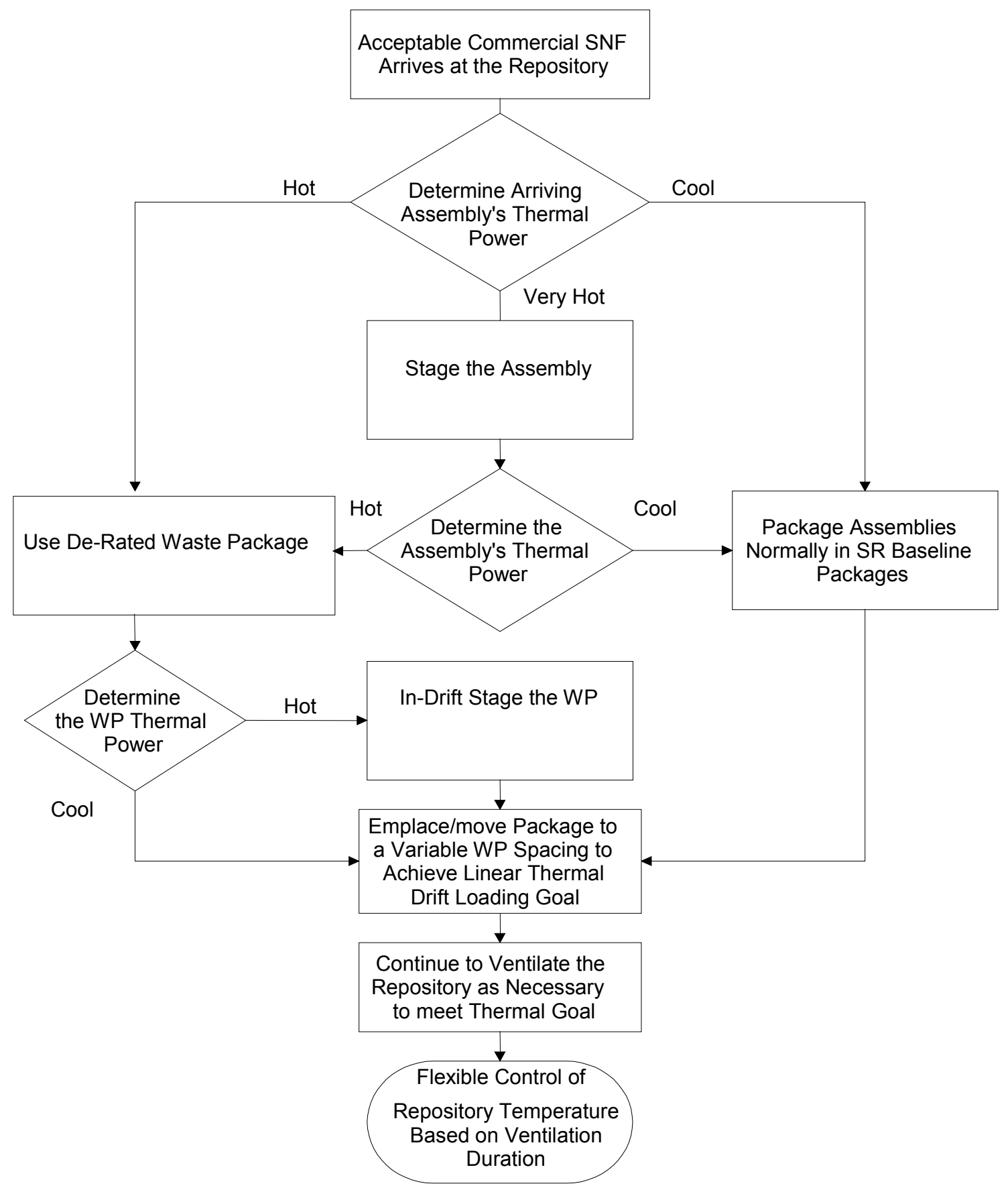

Figure 4-5. Thermal Operating Methodology for Alternative D 


\section{CONCLUSION AND RECOMMENDATION}

The thermal operating parameters (i.e., staging, WP loading and size of the WP, ventilation flow rate and duration, WP spacing and drift pitch) can be varied to support the desired thermal strategy after repository closure. The WS that is ultimately provided by the utilities will effect these parameters. The Thermal Operating Methodology presented in the graphic presentation of these parameters can be utilized by the decision-makers to achieve the desired results. The repository can be operated at a low thermal operation mode (i.e., WP surface temperature of 85 degrees Celsius or less) or at higher temperatures. This strategy allows the maximum flexibility of operation of the repository to support the overall needs. Following the flow charts presented in Section 4 will help the decision-makers to understand the engineering evaluations (i.e., WP temperature, WS, ventilation duration, WP spacing, and drift pitch) needed to obtain the desired operation. Final decisions will have to be made at the time of waste receipt, prior to emplacement, when the actual WS characteristics are understood. 


\section{REFERENCES}

\subsection{DOCUMENTS CITED}

Anderson, M.J. 2002. "Supporting Information for Non-Q Report.” E-Mail from M. Anderson to J. Frey, April 3, 2002. URN-1036. [DIRS 157973]

BSC (Bechtel SAIC Company) 2001. Technical Work Plan for Subsurface Design FY 02 Work Activities - Design Requirements and Re-Evaluation of Design Concepts. TWP-MGR-MG000004 REV 00. Las Vegas, Nevada: Bechtel SAIC Company. ACC: MOL.20011023.0138. [DIRS 156922]

BSC (Bechtel SAIC Company) 2002a. Modular Design Implementation System Evaluation for License Application. TDR-CRW-SE-000023. Las Vegas, Nevada: BSC. URN-1029. [DIRS 157891]

BSC (Bechtel SAIC Company) 2002b. National Transportation Options for the Modular Design Implementation System Evaluation for License Application. TDR-WAT-SE-000005. Las Vegas, Nevada: BSC. URN-1030. [DIRS 157892]

CRWMS M\&O 2000a. Drift Scale Thermal Analysis. CAL-WIS-TH-000002 REV 00. Las Vegas, Nevada: CRWMS M\&O. ACC: MOL.20000420.0401. [DIRS 143128]

CRWMS M\&O 2000b. Waste Packages and Source Terms for the Commercial 1999 Design Basis Waste Streams. CAL-MGR-MD-000001 REV 00. Las Vegas, Nevada: CRWMS M\&O. ACC: MOL.20000214.0479. [DIRS 138239]

Curry, P.M. 2001. Monitored Geologic Repository Project Description Document. TDR-MGRSE-000004 REV 02 ICN 02. Las Vegas, Nevada: Bechtel SAIC Company. ACC: MOL.20010628.0224. [DIRS 154136]

DOE (U.S. Department of Energy) 1995. The Nuclear Waste Policy Act, As Amended, With Appropriations Acts Appended. DOE/RW-0438, Rev. 1. Washington, D.C.: U.S. Department of Energy, Office of Civilian Radioactive Waste Management. ACC: HQO.19950124.0001. [DIRS 122137]

DOE (U.S. Department of Energy) 1999a. Waste Acceptance System Requirements Document. DOE/RW-0351, Rev. 03. Washington, D.C.: U.S. Department of Energy, Office of Civilian Radioactive Waste Management. ACC: HQO.19990226.0001. [DIRS 110306]

DOE (U.S. Department of Energy) 1999b. Draft Environmental Impact Statement for a Geologic Repository for the Disposal of Spent Nuclear Fuel and High-Level Radioactive Waste at Yucca Mountain, Nye County, Nevada. DOE/EIS-0250D. Summary, Volumes I and II. Washington, D.C.: U.S. Department of Energy, Office of Civilian Radioactive Waste Management. ACC: MOL.19990816.0240. [DIRS 105155] 
DOE (U.S. Department of Energy) 2000. Quality Assurance Requirements and Description. DOE/RW-0333P, Rev. 10. Washington, D.C.: U.S. Department of Energy, Office of Civilian Radioactive Waste Management. ACC: MOL.20000427.0422. [DIRS 149540]

DOE (U.S. Department of Energy) 2001. Yucca Mountain Science and Engineering Report. DOE/RW-0539. [Washington, D.C.]: U.S. Department of Energy, Office of Civilian Radioactive Waste Management. ACC: MOL.20010524.0272. [DIRS 153849]

DOE (U.S. Department of Energy) 2002. Final Environmental Impact Statement for a Geologic Repository for the Disposal of Spent Nuclear Fuel and High-Level Radioactive Waste at Yucca Mountain, Nye County, Nevada. DOE/EIS-0250F. Washington, D.C.: U.S. Department of Energy, Office of Civilian Radioactive Waste Management. ACC: MOL. 20020207.0344 through; MOL.20020207.0349. [DIRS 155970 ]

Gillespie, S. 2002. “CSNF Bounding Parameters.” E-mail from S. Gillespie to J. Frey, March 15, 2002. URN-1032.[DIRS 157824]

Ryman, J. 2002a. “Average Waste Package Decay Heat at Emplacement for 63K MTHM SYFF5 Waste Stream.” E-Mail from J. Ryman to J. Frey, March 14, 2002. URN-1034. [DIRS 157894]

Ryman, J. 2002b. “Average Waste Package Decay Heat at Emplacement for 63K MTHM SYFF5 Waste Stream without Staging.” E-Mail from J. Ryman to J. Frey, March 28, 2002. URN-1033. [DIRS 157895]

Linden, A. 2002. "Preliminary Excavation Quantities." E-mail from A. Linden to J. Frey, March 19, 2002, with attachment. URN-1035. [DIRS 157826]

Ryman, J. 2002c. "Differences between the Old WS and the New." E-mail from J. Ryman to T.L. Mitchell, January 30, 2002, with attachment. ACC: MOL.20020204.0120. [DIRS 157825]

Waisley, S. 2001. "Technical Direction to Bechtel SAIC Company, LLC, Contract Number DEAC08-01RW12101; TDL No. 02-003.” Letter from S. Waisley (DOE) to K. Hess (BSC),

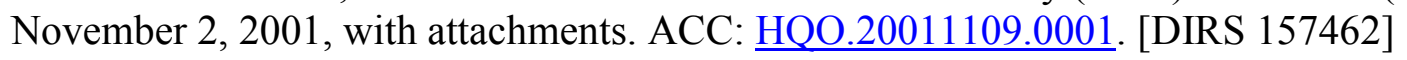

\subsection{CODES, STANDARDS, REGULATIONS, AND PROCEDURES}

AP-3.11Q, Rev. 3, ICN 0. Technical Reports. Washington, D.C.: U.S. Department of Energy, Office of Civilian Radioactive Waste Management. ACC: MOL.20020102.0338. [DIRS 157281]

AP-SI.1Q Rev. 3, ICN 3. Software Management. Washington, D.C.: U.S. Department of Energy. ACC: MOL.20020102.0200. [DIRS 157557] 